\title{
Relativism in Richard Rorty's Political Morality
}

\author{
Thomas $\mathbf{M}^{*}$ \\ Jordan University College, Tanzania
}

*Corresponding author: Monchena Thomas, Jordan University College, P.O BOX 1935

Morogoro, Tanzania, Tel: +255629489213; Email: monchenatom@gmail.com

\section{Research article}

Volume 4 Issue 4

Received Date: September 20, 2021

Published Date: October 19, 2021

DOI: $10.23880 /$ phij-16000200

\section{Abstract}

This paper results from a study in the philosophy of Richard Rorty, an American, postmodern and pragmatist philosopher. The general focus is to deepen our understanding of the nexus between morality and politics and how this interplay (if it does exist) could be (or is) affected by some philosophical trends in the postmodern era. In this epoch which is characterized by varied democracies, globalization, free trade, and technological advancement, politics appear to be "divorced" or emancipated from morality. It is not a rare phenomenon that choices in politics (by the political governments) and the political policies are made in disregard to moral principles. Many of the political choices and policies we witness, either on national or international level, are made to the violation of rational moral standards. Politics has become shorn of morality.

Keywords: Philosophy; Richard Rorty; Pragmatism; Morality; Politics

The specific philosophical trend that we are focused on is the pragmatism as espoused by Richard Rorty. Rorty's pragmatism is characteristically relativist, and as such has implication on the relationship between morality and politics. Because values relative and limited to locality and culture, then there is no possibility of a more universal ethical values applicable universally. Rorty strongly believes that moral values and political good can justified only in the temporal and cultural context, that is, ethnocentrically. Thus, the interplay between morality and politics for him cannot be at the universal level. This is anchored in the belief that human beings have no shared, common standards on the basis on which we can understand one another in a universal level. Human beings do not have a common nature. Without a common nature as a basis for universal standard of moral truth and political good, we are left only with multiple standards of truth and goodness.

This relativistic position means that different people arrive at different understandings, and that there are no basic moral demands that apply to everyone. While so, at a local level, there is a possibility of an "ethnocentric" community, "our community" - made up of those who share beliefs. This creates a platform for politicians to consider themselves a unique "community" which is exonerated from some moral demands.

The paper begins by attempting to demonstrate the relativism in Rorty's philosophy and then it tries to shows the implication of his philosophy on the relation between politics and morality.

\section{Relativism in Richard Rorty's Political Morality}

From the ancient times, political philosophy and ethics were considered to be two parts of single practical inquiry. Politics and political actors were characterized or were required to be characterized by moral excellences-the moral virtues. The relationship between morality and politics takes twist under the contemporary tenets of skepticism and relativism. Relativism and skepticism are not synonymous terms, but despite their differing there is a way in which relativism and skepticism are related; and it is that 


\section{Philosophy International Journal}

relationship that justifies our lumping together 'relativism' and 'skepticism' in considering their effects (when they are asserted) on the relationship between morality and politics.

Relativism is a disposition towards the view that establishment of truth is dependent upon the mind establishing that truth. ${ }^{1}$ Thus, a relativist is typically one who believes and attempts to argue that there is no objective, universal standard of assessment or judgment between different standpoints, given that we do not have a "universal mind" upon which the establishment of "universal standards" is dependent.

There may be many different sorts of relativism, but usually they are considered to have two features in common: first, they all assert that knowledge, values, beliefs, or understanding are all relative to some particular conceptual scheme or framework. Second, they all deny that any standpoint is uniquely privileged over all others. Richard Rorty, for example, understands relativism as a view that "every belief on a certain topic, or perhaps about any topic, is as good as every other."

Skepticism, in turn, is an epistemological process or method of applying reason and critical questioning with the aim of arriving at the necessary conditions by which truth may be established as unprejudiced knowledge. Some people become skeptical (doubtful) about the truth of moral claims and they begin to think that there is no truth or at least no truth discoverable by human beings. With this understanding, skepticism seems to promote relativism by: (i) exposing how unwarranted human knowledge and beliefs are; (ii) by exposing the limitations to understanding, and sometimes how what is claimed to be knowledge amounts to nothing more than beliefs, opinion; (iii) by exposing how hard it is to understand anything to the degree we would like to think we do.

An immediate example or representative of this view is Richard Rorty. However, Rorty preferred being labeled as "pragmatist" than as "relativist". In some of his writings he refutes the criticisms of those who tag him as a relativist, arguing that he is a pragmatist and that pragmatists do not believe that anything goes; for they believe that some views are better than others yet they are not absolute. ${ }^{3}$

1 Relativism is thought to spring from two key problems; the problem of diversity and the problem of value conflict. For moral relativists, all that is required to prove the possibility of relativism is the overwhelming diversity of moral standards across history and across the contemporary world.

2 R Rorty, "Pragmatism, Relativism, and Irrationalism" in Proceedings and Addresses of the American Philosophical Association, 53 (1980), pp. 718-738, 727.

3 R Rorty, "Pragmatism, Relativism, and Irrationalism" in Proceedings and Addresses of the American Philosophical Association, 53(1980), pp. 718-738,
Richard Bernstein suggests that Rorty is not convincing with this defense. Bernstein is convinced that Rorty does more than commend his view - in fact, he argues against absolutism, universalism and other philosophical positions like essentialism and foundationalism. The standards of reasoning he uses in these arguments are ones he believes are good, not merely ones which he happens to have picked up and developed a fondness for. ${ }^{4}$

We share Bernstein's position, that relativism is apparent in Rorty's thought; therefore he cannot easily escape the accusations of being an advocate of relativism. I think that Rorty's rejection to be tagged as relativist is perhaps his strategy which is motivated by the need to be consistent to his own advice that philosophy needs to get out of the habit of using certain words, and learn to adopt others. By changing the vocabulary, Rorty hopes to be able to change the subject and thus deny his critics their "choice of weapons". In his article "the Contingency of Community" Rorty writes that: If one says, as I did in 'The Contingency of Language', that truth is not 'out there', one will be suspected of relativism and irrationalism. If one suggests, as I then did in 'The Contingency of Selfhood', that we no longer need a distinction between morality and prudence, one may seem to be encouraging immorality. By way of defence, I shall argue here that these distinctions between absolutism and relativism, rationality and irrationality, morality and expediency, are obsolete and clumsy tools - remnants of a vocabulary which we should try to replace. [...]. So my strategy will be to try to make the vocabulary, in which these objections are phrased to look bad, thereby changing the subject, rather than granting the objector his choice of weapons and terrain by meeting his criticisms head-on. ${ }^{5}$

Rorty considers himself one among the "edifying philosophers".6 He characterizes edifying philosophers as "skeptical primarily about systematic philosophy, and about the whole project of universal commensuration." ${ }^{77} \mathrm{He}$ further indicates that the goal of an edifying philosopher qua philosopher is that of offering arguments, and "to offer another set of terms, without saying that these terms are the

727; R. RoRTY, Philosophy and the Mirror of Nature, Princeton University Press, Princeton, New Jersey 1979, pp. 373-379; R. RoRTY, Objectivity, Relativism, and Truth, Philosophical Papers, vol. 1, Cambridge University Press, Cambridge 1991, pp. 22-24.

4 R. Bernstein, The New Constellation: The Ethical-Political Horizon of Modernity/Postmodernity, Polity Press, Cambridge 1991, pp. 242, 358-60.

5 R Rorty, "The Contingency of Community" in London Review of Books, 8(1986), pp. 10-14, 10.

6 Rorty makes a distinction between mainstream philosophers or what he calls "systematic philosophers" and peripheral or what he calls "edifying philosophers". See R. RoRTy, Philosophy and the Mirror of Nature, Princeton University Press, Princeton, New Jersey 1979, pp. 367-368.

7 R Rorty, Philosophy and the Mirror of Nature, p. 368. 


\section{Philosophy International Journal}

new-found accurate representations of essences." ${ }^{8}$ For Rorty, when the edifying philosophers do edification philosophywhich instead of attempting to "discover the truth", seeks to keep the "conversation" ongoing-thus, helping their readers or society as a whole to break free from outworn vocabularies and attitudes. This "liberation" from the worn out words is, according to Rorty, already happening in Europe, which has "gradually lost the habit of using certain words and gradually acquired the habit of using others."

We now proceed to demonstrate in brief, the relativistic elements in Rorty's thought; and how adopting his ideas or similar positions does or can affect the interplay between morality and politics. We begin with Rorty's argument that there is no objective truth, and that no one has rightly grasped reality. In Truth and Progress, Rorty writes that: We have learned (from Nietzsche and James, among others) to be suspicious of the appearance-reality distinction. We think that there are many ways to talk about what is going on, and that none of them gets closer to the way things are in themselves than any other. We have no idea what 'in itself' is supposed to mean in the phrase 'reality as it is in itself'. So we suggest that the appearance-reality distinction be dropped in favor of a distinction between less useful and more useful ways of talking. ${ }^{10}$

In the above citation, Rorty is pessimistic about truth. For him objectivity is something unachievable and that we can only discover what is best for a particular community or culture any time in history. Rorty sustains that, when we claim that a statement like "snow is white" is "true", all we are really saying is just that it is accepted by the particular culture in which the statement is made. We consider this to be Rorty's full-fledged historicism which is a form of relativism. His historicism is intimately linked to what he calls his "ironist" position.

Roughly, the ironist is a nominalist and historicist who strives to retain a sense that the vocabulary of moral deliberation she uses is a product of history and chance - of her having been born at a certain time in a certain place. ${ }^{11}$

In effect, Rorty's historicism culminates in his claim that we can no longer credibly "ground" our values, beliefs, and ideas in any "universal ground", whether it is God, Reason, or Nature. ${ }^{12}$ It is on that basis that Richard Rorty is considered

8 R Rorty, Philosophy and the Mirror of Nature, pp. 367-371.

9 R Rorty, Contingency, Irony, and Solidarity, Cambridge University Press, New York 1989, p. 6.

10 R Rorty, Truth and Progress: Philosophical Papers, Vol. 3, Cambridge University Press, Cambridge 1998, p. 1.

11 R Rorty, Truth and Progress: Philosophical Papers, Vol. 3, p. 307.

12 "They [William James and John Dewey] asked us to liberate our new an anti-foundationalist and relativist. According to him, "there is no wholesale, epistemological way to direct, or criticize, or underwrite, the course of inquiry." ${ }^{\prime 13}$ It means all our moral beliefs, moral ideas, values, and theories are to be seen as local, cultural formations, rooted in and confined to particular time and place. He believes that no perspective or standpoint is final, and any position must be replaced if a better one comes along. And this is so because there is no independent 'truth standard' to decide which one is the final standpoint among many different positions. However, Rorty does not tell us how to determine a "better position" without any reference to foundations.

\section{The Implication of Rorty's Relativism on the Nexus between Politics and Morality}

The logical implication of the above view on the interplay of morality and politics is that, the relationship of these two should be limited to the context of the same historicism that Rorty expresses. That is, the relationship between morality and politics should also be local, confined to time and place or culture. He believes that the justification of moral values and political good can be done in our temporal and cultural context. Richard Rorty, proposes "ethnocentrism" as the suitable view of the justification of truth claims; more particularly truth claims about moral values and political good life. He says that one cannot go beyond one's own society's procedures of justification. For him, "everything one can say about truth or rationality is embedded in the understanding and concepts unique to the society in which one lives." ${ }^{14}$

From Rorty's perspective, the interplay between morality and politics cannot take a universalistic approach. The relationship between morality and politics for him can only be at the local level-and not in the universal level. The reason underlying this view is that we as human beings have no shared, common standards on the basis on which we can understand one another in a universal level. Human beings do not have a common nature. In fact, for Rorty nothing has an essential nature or teleology. ${ }^{15}$ He thinks that realists

civilization by giving up the notion of 'grounding' our culture, our moral lives, our politics, our religious beliefs, upon 'philosophical bases'.' See R Rorty, "Pragmatism, Relativism, and Irrationalism" in Proceedings and Addresses of the American Philosophical Association, pp. 720-721.

13 R Rorty, "Pragmatism, Relativism, and Irrationalism" in Proceedings and Addresses of the American Philosophical Association, p. 722.

14 R Rorty, Objectivity, Relativism, and Truth, Cambridge University Press, Cambridge 1991, p. 11.

15 Rorty's belief that nothing has an essential nature is the basis of his rejection of the capacity of the human mind to know the essential reality of any object. He thinks philosophical problems have never been solved because philosophy, from Plato to Neo-Kantians, has erroneously conceived the human mind as "mirror of nature." 


\section{Philosophy International Journal}

are wrong in maintaining the view that there is something within each of us-our essential humanity-which exists in other human beings. For him, there is no such "ahistorical" thing as "essential humanity". ${ }^{16}$ Consequently, without a universal standard of truth based on the nature of things, we are left only with multiple standards of truth, reasoning and morality. This means that different people arrive at different understandings, and that there are no basic moral demands that apply to everyone. While so, at a local level, there is a possibility of an "ethnocentric" community, "our community" - made up of those who share beliefs.

To be ethnocentric is to divide the human race into the people to who one must justify one's beliefs and the others. The first group - one's ethnos-comprises those who share enough of one's beliefs to make fruitful conversation possible. In this sense, everybody is ethnocentric when engaged in actual debate, no matter how much realist rhetoric about objectivity he produces in his study. ${ }^{17}$

Rorty's relativism is also unveiled by his usage of the notion of "solidarity" instead of "objectivity". ${ }^{18}$ In Objectivity, Relativism, and Truth Rorty makes a distinction between objectivity and solidarity. Objectivity for him is the attempt to discover a relationship between human beings and a nonhuman reality. Implicit in the notion of objectivity is the

16 R Rorty, Contingency, Irony, and Solidarity, Cambridge University Press, New York 1989, p. 189.

17 R Rorty, "Solidarity or Objectivity," in Objectivity, Relativism, and Truth, Cambridge University Press, Cambridge 1991, p. 30.

18 The rejection of objectivity in favor of solidarity is central in Rorty's version of pragmatism. belief that there is some ahistorical, non-human reality to which things must correspond. Solidarity, according to him is limited to a community or particular society. Solidarity, he says, is the point of reference within an historical community. In this case, the attempt is to seek the relation between practices of a community within that community and not outside of it. According to him we should hope for a culture in which questions about truth, the "objectivity of value" or the "rationality of science" would seem equally unintelligible. Pragmatists would like to replace the desire for objectivity the desire to be in touch with a reality, which is more than some community with which we identify ourselves - with the desire for solidarity with that community.

\section{Conclusion}

Richard Rorty is a relativist, and his position regarding truth claims is unfavorable to the healthy relationship between the political and the moral. We believe there should be no neutral ground where politics and morality are divorced from each other by claiming that it is impossible to objectively know the right standards - what is good and what is not-the state is required to refrain from supporting laws or policies on the basis of our conception of the good and the truth. Rorty's position is a good theoretical ground for those who claim that politicians must never consider the universal moral principles during their decision-making on issues that concern the public. Meaning that politics and morality must operate in separation; because the criteria by which political choices are made are not morally founded. Instead they are founded on political expediency (opportunity), utility and personal interests of the statesman.

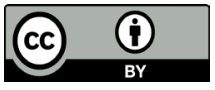

